\title{
THE POSTPANDEMIC WORLD: THE (IM) POSSIBILITY OF PRODUCTIVE CHANGES
}

\author{
Radmila Nakarada ${ }^{1}$ \\ Faculty of Political Science, University of Belgrade
}

\begin{abstract}
The author situates the discussion of the post-pandemic world amidst the contradicting features of the present, the accumulation of advances and dramatic problems. She discusses the pessimistic and optimistic interpretations of the possible outcomes, from catastrophic to productive. The rest of the paper is devoted to the discussion of the hurdles standing in the way of resolving the pandemic crisis wisely and creating a "better normal".
\end{abstract}

Keywords: COVID-19 pandemic, global system, authoritarianism, "better normal".

\section{Introduction}

The complex reality, colored by impressive scientific, technological and economic advances and dramatic social, economic and ecological problems, ethical shortcomings threatening the very existence of the human species, is difficult to discern. The tying together of the spectacular and apocalyptical, the processes of long duration and the intervening future, seem to demand a new round of theoretical efforts, combining a critical outlook and humility. This is a good moment to be reminded of Herbert Marcuse's thoughts on technology: "Not only is the application of technology but technology itself domination (of nature and men) - methodical, scientific, calculated, calculating control. Specific purposes and interests of domination are not foisted upon technology 'subsequently' and from the outside; they enter the very construction of the technical apparatus. Technology is always a historicalsocial project: in it is projected what a society and its ruling interest intend to do with men and things." (1968, pp. 223-224).

The COVID-19 pandemic is by and large defined as an epic global crisis. Crisis (Antentas 2020) in principle can be treated as a moment of judgment, revelation of glaring deficiencies, failures, mistaken priorities, a "worsening of the situation", and/or as a moment of choice, a turning point offering different possibilities: a chance to recapture wisdom and initiate productive changes, or preserve the prevailing matrix of life, i.e. sustain (a slightly reformed) status quo. ${ }^{2}$ In the words of Fareed Zakaria (2020), the ugly pandemic has "created the possibility for optimism, change and reform. It has opened path to a new world. It's ours to take that opportunity or to squander it." Which capacities, outcomes will prevail depends on the strength/power, aspiration, quality of insights of contending social forces and their "distinct projects that are put forwards in response to the crisis, political conditions and contingency all within the bound of what is structurally possible." (Robinson 2014, pp. 158-159).

1 Contact address: radmila.nakarada@gmail.com.

${ }^{2}$ Antentas quotes Walter Benjamin (Passagenwerk, 1940), who notes that the fact "that things are 'status quo' is the catastrophe." op. cit 
The cumbersome and multifold consequences of the COVID-19 pandemic crisis have generated both pessimistic and optimistic visions of the post-pandemic world. Moderate pessimist's fear no changes will ensue, another crisis will pass, like the 2008 financial crisis, leaving essentially intact the logic of neoliberal capitalism, turning the future into a return to the "bad normal". Mariana Mazzucato (2020) argues:

"Some who talk about recovering from the pandemic cite an appealing goal: a return to normalcy. But that is the wrong target; normal is broken. Rather, the goal should be, as many have put it, to 'build back better'. Twelve years ago, the financial crisis offered a rare opportunity to change capitalism, but it was squandered. Now, another crisis has presented another chance for renewal. This time, the world cannot afford to let it go to waste."

Radical pessimists perceive the possibility of tragic outcomes, an intensification of authoritarian dimensions, expansion of instruments and modes of Orwellian control and ever deeper inequality-leading to $21^{\text {st }}$ Fascism. On the other hand, optimistic visions span from a reformed capitalism ${ }^{3}$ combining "resilience and sustainable growth", (Zakaria 2020), i.e. a new green deal, to the reinvention of communism (Zizek 2020). Optimists believe that the pandemic has dethroned neo-liberalism as a sustainable and effective paradigm, ushered the end of global domination by the West, and affirmed the necessity to tend carefully to social needs, transcend reckless greed with solidarity and eco responsibility. The pandemic is treated as a global crisis that speaks with clear imperatives for productive changes of the present- peaceful cooperation, rehabilitating brotherhood, equality, and the common good, practicing responsible self-restraint.Gary Moreau (2020) in his review of Zakaria's book Ten Lessons for a Post-pandemic World argues, interpreting Confucius, that "behavior can only be changed through the self-restraint imposed by a moral code built around a personal sense of obligation." This means transcending selfishness and affirming the common good.

However, the optimistic expectations that the pandemic crisis, together with the economic and ecological crisis, has reached such heights that productive changes/ transformations are a realistic expectation, may be once again betrayed. Simply because the modes of response of those privileged by the present globally dominant neoliberal order fundamentally resist the imperatives. In other words, betrayal is indicated in the unequal impact of the pandemic, hitting more lower wage workers, women, blacks, i.e. securing the continuation of an order that enables "the rich getting richer and the poor poorer" without major disruption (Parker et al 2020). Betrayal is indicated in the uninterrupted militarization of the world, further worsening of relations between key global actors (new Cold war), in the nestling of the Corona-19 challenge in geostrategic rivalries and mutual suspicion, as well as in the weakness of international organization, above all the UN and the WHO. Transformative limits are inscribed also in the forms of resisting the noted imperatives by the victims of the prevailing order in relation to the measures against Covid-19 and the policy of vaccination. This further polarizes and divides societies exposing the breadth of mistrust, confusion, and manipulation, the blurring of issues (human rights vs. public health), political positions (left/ right) and the prevalence of inadequate capacities of the victims of neoliberal domination to "connect the dots".

3 Fareed Zakaria underlines in the cited article that no Revolution is necessary because significant political and economic advancements have been made. 
For the time being, the pandemic crisis, although producing faltering problems does not seem to be swaying the dominant paradigm along the path of transformative changes. ${ }^{4}$ In spite of the destabilizing, chaotic effects of the pandemic crisis, the walls of (nontransparent and unaccountable) power and the obscene privileges ${ }^{5}$ of the dominating tiny minority are visibly left intact or even increased. ${ }^{6}$ The de-privileged majority, on the other hand is confined to narrow self-interests, and stratified by indifference, instrumentalization, and confusion. It seems that once again we may be confronted with the capacities of the prevailing order and the privileged $1 \%$ to adjust, come to grips with the crisis in such a manner to preserve and expand and strengthen their domination. To paraphrase A. Gramsci, the ruling class has a greater capacity and resources to change programs and cadres, and with greater speed than the subordinated reabsorb, reinforce their control. If this was not so, then noticeable turnabouts would be registered in the realms of military expenditure, radical solidarity and decreasing inequalities, the growing power and participation of the citizens as choice-makers. This, among else, means that the diagnostic reach of social theory in understanding the character of power and its new locations and actors, as well as the distorted responses of the victims of domination has to be reconsidered.

4 Zakaria, considers the fact that the US government opened its coffers and provided emergency financial aid to certain parts of the vulnerable strata of the population and recognized the "essential workers" giving them public credit for their role in combating the virus, an encouraging positive sign with a transformative potential. Cornell West in a conversation with Richard Wolff, questioned the reach of the recognition of the "essential workers" by a disturbing example of their treatment in New Orleans. There garbage collectors were fired for asking for protective equipment and an increased pay (from \$10.51 per hour to \$15) due to the dangers of their work (garbage is full of corona virus). They were replaced by prison inmates who not only were not provided with protective equipment, but were paid \$1.33 an hour. Economic Update: Cornel West on Pandemic Capitalism, www.democracyatwork.info posted by Richard Wolff, June 01. 2020.

${ }^{5}$ One example of this type of obscene extravagance widely noted in the media, is the tourist four minute space flight of Jeff Bezos founder of Amazon.com Inc (worth \$191billion according to the WSJ 0ct. 11, 2021 www.wsj.com) which cost $\$ 5.5$ billion. His space adventure whose tremendous costs in the midst of a pandemic could have been put to much better use, were solidarity, empathy, moral self-restraint in place. Joe McCarthy from Global citizen notes seven problems where this money could have been of help. Among the seven are saving 37.5 million from starvation, helping to vaccinate the world, by fully funding COVAX and securing vaccines for 2 billion in low income countries, fully funding humanitarian efforts in Nigeria, DR Congo, Afghanistan, Yemen, Venezuela, Horn of Africa, and preventing untold suffering together with the UN. Funding 3 billion children displaced from schools as a result of Covid-19; helping countries adapt to climate change, by helping them invest in renewable energy, and restoring ecosystems. See: Joe McCarthy, "Jeff Bezos Just spent $\$ 5.5$ billion to be in space for 4 minutes. Here are 7 Things That Money Could Help Solve", www.globalcitizen.org, July 2021.

6 According to New York Times 40 million Americans filed for unemployment during the pandemic, tens of millions of families now reporting that they don't have enough to eat ("US Jobless Claims pass 40 million", 20 January 2020). On the other hand, billionaires saw their new worth increase by half a trillion dollars. The government disproportionately gives more aid to larger companies. Plus wealth friendly tax laws and loopholes keep those billionaires at the top. (See: Business Insider, "How Billionaires Got $\$ 637$ billion richer During the COVID-19", 30 October 2020). 


\section{Lost chances}

In stressing that the chance for the global system to move in a better direction, in accordance with human needs, social justice, international cooperation and eco sustainability, and not squandering the opportunities, usually the crisis of 2008 is mentioned as a case in point. However, before the 2008 financial crisis, the end of Cold war opened the possibilities for stable peace, constructive cooperation/partnership, demilitarization, above all denuclearization, efficient economic development which have also been overrun by the adherence to the hegemonic aspirations and neoliberal expansionism (Nakarada 2021). Today, in the midst of the pandemic, we are talking about a New cold war between China and USA, and the continuation of the Cold War between US and Russia - both parties claiming that their relations have reached the lowest level since 1989, mutually perceiving each other as a primary security threat requiring a new round of armament. The space between the celebration of the end of Cold War, and reviving its current mode, we first have the fall of one wall and the erection of at least 13 new walls on the borders of EU countries and within the Schengen space; the dismantling of communism leaving no space for reform in the direction of democratic socialism, for instance in East Germany and Russia toward which the citizens were inclined. TINA dictum allowed only neoliberal cooption, its extension to new frontiers via shock therapy and all its unfortunate social consequences unemployment, inequality, radical privatization(Vankovska 2020). The abolishment of the Warszawa pact, the pulling out of the Soviet army ' $2000 \mathrm{~km}$ from Berlin' did not lead to the dismantling of the NATO (but its enlargement), and long term disarmament. It took a decade for antagonistic relations to resume, and definitely be installed after the Crimean episode in 2014, when Russia was accused of attempting to reassert itself as an imperial power and categorized as a prime security threat to the West. According to Mearsheimer (2014), the West is responsible for the Ukraine Crisis because NATO, EU and US wanting to expand to the East, intervened in the political process of Ukraine in order to bring changes that would allow the inclusion of Ukraine in its orbit.

The New Cold war between US and China, has also been gaining steam. Here one should note the observation of Vijay Prashad (Democracy Now! 2021) that China is not a military threat to the US but a serious competitor in the realm of new technologies, and in some significant domain surpassing the US. Besides a trade war, and policy of sanctions, in the midst of the pandemic the US created a new security alliance with Australia, UK (AUKUS) aimed against China.

This brief note on the end of Cold War shows that an event of such magnitude (according to some a definite end of the Second World War) encompassing the end of ideological divide, unification of Germany, return of Eastern Europe to the West, initial decrease of military expenditures, could not transcend in the long run, the deeply rooted logic of antagonism, rivalry, nor extend the form of transformation to anything but the imposing neoliberal model.

Mutual accusations, policy of sanctions and counter sanctions, lack of dialogue, military provocations have not only continued during the pandemic, but gained in intensity in spite of the fact that all three key global actors have been hit hard by virus. The pandemic challenges have not contributed to the easing of the relations, to cooperation. Instead 
geopolitical rivalry increased in intensity. Mobility becomes tied to which vaccine was taken, that is, travel to the West was possible only if a person was vaccinated by western vaccines. The offering of Russian (and Chinese) vaccine was perceived as an instrument of extending unacceptable geopolitical influence.

The continuity and even intensification of noted tensions are providing grounds for a cynical conclusion that the pandemic calamity is not (yet) of a sufficient magnitude to prompt reasonable turnabouts to normality, de-escalation i.e. international cooperation required by the ongoing challenge. As a metaphor of this stubborn power of the irrational, stands small Cuba, which continues to suffer because of long US blockade/ sanctions from combined problems related to the pandemic and shortages of food. More than 243 coercive measures Tramp introduced to further strangulate Cuba, Biden did not suspend or ease in spite of the pandemic although he did proclaim the US "stands firmly with the people of Cuba" (Global Times 2021). The unnecessary suffering of the Cuban people still makes sense within prevailing propositions shaping the world order.

\section{Reordering priorities - the question of military expenditures}

With the end of Cold war, the disappearance of the Warsaw pact, the decrease of military expenditure of Russia, widespread hopes/expectation were generated that the world was on its way to a stable peace, and that logically this would result in the reordering of priorities, i.e. significant decrease in military expenditures, renouncing of nuclear arms and investing more in the wellbeing of citizens, in their health and education. Three decades later and in the midst of the pandemic, we see that world military expenditures has not decreased, but reached an all time high - \$1.981 billion (SIPRI 2021). Military expenditure, after a short break following the end of the Cold War, has been rising since, particularly from 2009 and the global pandemic situation has not interrupted this trend. The SIPRI Report in fact notes that the increase of $2.6 \%$ in the first year of pandemic came in a year when global GDP shrank by $4.4 \%$. The five biggest spenders, the US, China, India, Russian and the UK account for $62 \%$ of the global military expenditure. The glaring paradox, particularly acute in the US, a country that spends the highest amount of all - $\$ 750$ billion, more than the combined amount of seven other top spenders, is at the same time a country that encountered severe problems in securing for its citizens elementary health protection when Covid-19 struck. As a result it is at the top of the list with 46 million cases of COVID infection and 748.000 cases of death.?

Some critical analysts (for instance Noam Chomsky) noted that US was not prepared for the pandemic, it did not stock masks, medication, ventilating machines, etc. because, stockpiling in the health realm is not profitable according to the neoliberal logic, while stockpiling of arms is. The adherence to the profit principle in the domain of health as the supreme principle may be defined as new barbarism, for it suspends the relevancy of Universal Declaration of Human Rights, European Social Charter, and other similar documents, affirming the responsibility of the state to provide for the basic social needs of its citizens. The trend of militarization (involving modernization of nuclear weapons, creation of new supersonic

7 Following US, India has 34.052 million cases and 452.008, deaths, while Brazil has 21.664 million cases and 602.201 deaths. See more on: https://www.worldometers.info. 
weapons, preparation for cyber wars, and militarization of space). Uninterrupted by the pandemic shows that the value of arms is greater than the value of human life.

\section{Inequalities}

Among the worst consequences of the reign of the global neoliberal economic order based on deregulation, privatization, austerity, the dramatic increase of inequalities within ${ }^{8}$ and between countries is usually cited. As J. Stieglitz states the last 4 decades capitalism has not been working for the majority, but for the $1 \%$ who "have it all but want more", who celebrate greed and indifference, hyper-individualism and create an illusion of their superior efficiency, expertise, and obscure the role of the state, the relationship between the public and private sector (Mazzucato 2020).

The pandemic situation has reinforced the inequalities, hitting as already cited the vulnerable segments of the population, low paid workers, women, racial minorities, and the institutionalized elderly. ${ }^{9}$ The effect of the pandemic, Dinah Fuentesfina from Act!onAid International describes in the following manner: "This truly is the inequality virus. We created vaccine billionaires but fail to vaccinate billions of people in desperate need. Given the vast public investment in the development of these vaccines and the overwhelming public health need throughout the world, these life-saving vaccines must be global public goods." (2021). The Big pharma's business model, ${ }^{10}$ their astronomical profits, are based on four elements: billions of public investment; patent monopoly; "charging exorbitant prices for life-saving medicines", (20 times the real cost for instance in the case of Pfizer) and paying low tax rates. This model is obviously beneficial "for wealthy investors and corporate executives but devastating for global public health." (R. Silverman).

The observations of D. Fuentesfina and R. Silverman are confirmed by the media reports on the earnings of the Big Pharma and their price policy, and by scientific analysis of the public-private relations. Forbes, The Guardian and the Financialtimes reported this summer that Pfizer expects to generate $\$ 33.5$ billion in COVID-19 vaccine in 2021, at the same time both Pfizer and Moderna raised their prices. Pfizer by $25 \%$ and Moderna by $13 \%$. As to the relationship between the public and private sector, M. Mazzucato (2020) points out that the pandemic has exposed how imbalanced it is: "In the Unites States, the National Institutes of Health (NIH) invests some $\$ 40$ billion a year on medical research and has been a key funder of the research and development of COVID -19 treatments and vaccines. But

${ }^{8}$ It is interesting to note that according to Washington post, "Billionaires have added about $\$ 1$ trillion to their total new worth since the pandemic began. Roughly one-fifth of that haul flowed into the pockets of Jeff Bezos and Elon Musk of Tesla and SpaceX fame. The two increased their new worth by a staggering $\$ 200$ billion last year, a sum greater than the gross domestic products of 139 countries. They could end all hunger in US eight time over. 200 billion accumulated by the two is greater than the amount of corona virus relief allocated to state and local governments in the CARES Act." Washington Post, "Jeff Bezos' and Elon Musk's wealth skyrocketed during the pandemic", 12 May 2021.

9 Some suspicion appeared in Sweden and UK concerning the lack of care of the elderly in old people's home during the pandemic resulting in a significant number of deaths. It seems that in UK some families who lost their family members in such institutions are going to sue the government.

10 The model is depicted by Robbie Silverman from Oxfam in the cited Act!onaid text. 
pharmaceutical companies are under no obligation to make the final products affordable to Americans, whose tax money is subsidizing them in the first place. The California-based company Gilead developed its COVI-19 drug, remdesivir, with $\$ 70.5$ million in support from the federal government. In June, the company announced the price it would charge Americans for a treatment course: $\$ 3,120 . "$

This all shows, together with the policy of low taxing, how systematically and to what extent public interests is subordinated to the private interests of the few. One should add to all that has been said, that the proposal of the WTO that relevant states should waive patents rights and support immediate transfer of vaccine technology to manufacturers in developing countries is on hold because it is opposed by Germany. In the background is the following reality. Only $4,4 \%$ of African population is fully vaccinated, some countries like Burundi and Eritrea have not yet even began the vaccination. Besides not waiving patent rights, the more fortunate countries who have vaccinated more than $66 \%$ of their population have not delivered their promised donations, nor has the UN COVAX program been able to implement its vaccination program. A moment of rational solidarity, for the pandemic which is a global problem and cannot be resolved by "vaccine hoarding by rich countries and profiteering by rich pharma companies, when millions across the world are being denied protection" ( $R$. Silverman), is squandered.

\section{Distortions}

The pandemic in many aspects is also an expression of the accumulated mistrust in government, science, self interest in Big companies. The air is full of contending interpretations, assurances, and confusing controversies. Harari (2018) says that science has triumphed and technology has eased the implementation of the required measures, pointing out that in short time, scientists were able to isolate the virus, discover its genome, and create vaccines. According to him all the chaos and failure is caused by political decision, not by the insufficiencies of science. Others say that none of the scientific endeavors related to the COVID-19 are indisputable. Everything is controversial, from the interpretation how the virus evolved, whether it has been transmitted from the bats, or created as a biological weapon by evil China, or evil US, whether the vaccines have been sufficiently tested, and whether the profit urgency ignores the danger of side effects, why should masks be worn. The public in many countries is divided into vaxxer and antivaxxer groups, the latter generating a mass of conspiracy theories via the social media. Research has discovered that a group of 12 antivaxxers, mostly having nothing to do with medicine, have had tremendous influence in increasing the confusion utilizing often misinformation. A particularly disturbing dimension of this confusion is that the left and right are sharing with ease conspiracy theories, or as $\mathrm{G}$. Monbiot (2021) says, conspiracy theories travel smoothly from right to left. In this voyage, origins of some ideas are forgotten, language swapped as Monbiot notes, so the left is now talking about security and stability and the right of liberation and revolt. The danger is that in this confusion, the need to find firm ground, to generate a rational dialogue and through debate resist the blindness of unfounded claims, may be lost. This could further decrease the capacity to understand the broader picture and the transformative options, fueling extremism and conflict. 


\section{Conclusion}

The pandemic is occurring at a historical stage in which the global system is acquiring authoritarian dimensions, substantially increasing its power of control (surveillance) and disciplining (Zuboff 2019), while counter/hegemonic forces are still weak, marginalized, too fragmented to act as a transformative force that can deal with the new forms, locations and instruments of power. The Left has not found its way amidst the turmoil of neo-liberalism and its advancement of the new stage of capitalism, and the victims have been deprived of understanding their own interests, of experiencing collective political action, directing their existential fears and anger at the Other, usually a fellow victim. Thus a Syrian refugee may appear as a greater hostile Other, than a CEO of Goldman and Sachs, or Pfizer, for example.

Now when we do not know what we are really facing, what is the origin, logic of the pandemic, when we need to carefully nurture scientific cooperation and dialogue, sensitive to the urgencies and the nuances, sincere about the dilemmas and prepared to act when credible scientific evidence, freed from political manipulation, emerges, we are facing a rather hostile environment. Paul French reminds of a valid chapter of pandemic experience (2020): "After pneumonic plague that took 60.00 lives in Manchuria, a conjunction of right knowledge, right resources, right people (scientists not politicians) met at a conference in Shenyang. A hundred years ago, only scientists saw a need for a global intergovernmental response. Main body of the conference focused on eliminating bad science, gossip and getting to the scientific root of the problem." Vaccines are treated on the one hand as if they are an intelligence matter (enemies are stealing from each other the formula), and on the other as a personal choice one has to make as a total amateur amidst all the contestations and controversies.

The sanctity of life, the productive balance between the individual and collective good has to be established and protected, but these concerns are overshadowed by the profit as the prime principle of the global order, militarization, coercion as the dominant mode of shaping amidst lack of protection, indifference and anger as a mode of belonging, insane wealth and suffering as alleged measure/expression of different biological and social capacities. This signifies to me that we have already squandered substantially the options for betterment. The question now is how far will this matrix be pursued, and whether there will be a post pandemic world or "pandemics" will become the constant ingredient of the new (not) normal, a prolonged confusing status quo.

\section{References}

Act!onAid(2021), "Pharmaceutical companies reaping immoral profits from Covid Vaccines yet paying low tax rates", 15 September, online https://actionaid.org/news/2021/ pharmaceutical-companies-reaping-immoral-profits-covid-vaccines-yet-paying-low-taxrates\#: :text=Moderna\%2C\%20BioNTech\%2C\%20and\%20Pfizer\%20are,People's\%20 Vaccine\%20Alliance\%20said\%20today..

Antentas, Josep Maria (2020), "Notes on corona crisis and temporality", Dialectical Anthropology,vol. 44, https://www.ncbi.nlm.nih.gov/pmc/articles/PMC7475023/.

Democracy Now! (2021), "Vijay Prashad Warns Biden is "Doubling Down" on Trump's Anti-China 
Cold War Policy", 16 March, online: https://www.youtube.com/watch?v=qJowngS4bwk.

French Paul (2020), "In 1911, another epidemic swept through China. That time, the world came together, CNN, 19 April, online https://edition.cnn.com/2020/04/18/china/greatmanchurian-plague-china-hnk-intl/index.html .

Global Times (2021), "US creates divide, not with China, but between humanity and imperialism: Indian scholar", 22 July, online https://www.globaltimes.cn/page/202107/1229305.shtml.

Harari, Yuval Noah (2018), 21 Lessons for the 21 ${ }^{\text {st }}$ Century, London: Jonathan Cape.

Marcuse Herbert (1972), Negations, Essays in Critical Theory, Harmondsworth: Penguin Books.

Mazzucato Mariana (2020), "Capitalism After the Pandemic, Getting the Recovery Right", Foreign Affairs, November/December, online https://www.foreignaffairs.com/articles/unitedstates/2020-10-02/capitalism-after-covid-19-pandemic.

McCarthy Joe (2021), "Jeff Bezos Just Spent $\$ 5.5 B$ to Be in Space for 4 Minutes. Here Are 7 Things That Money Could Help Solve". Global citizen, 20 July, online https://www.globalcitizen. org/en/content/jeff-bezos-space-flight-money-better-uses/.

Mearsheimer, John (2014), "Why the Ukraine Crisis is the West's Fault", Foreign Affairs, September/October.

Monbiot George (2021), "It's shocking to see so many leftwingers lured to the far right by conspiracy theories", The Guardian, 22 September 2021, online https://www.theguardian.com/ commentisfree/2021/sep/22/leftwingers-far-right-conspiracy-theories-anti-vaxxers-power.

Moreau Gary (2020), "Collectivism vs. individualism: Our choice will define the post-pandemic world", October 11, online: https://www.goodreads.com/review/show/3588883835.

NakaradaRadmila (2021), "Pad Berlinskogzidatridesetgodinakasnije- pogled s periferije", u D. Simić, et al. el (ured.): Srpsko-američkiodnos: Tridesetgodina od pada Berlinskogzida, Beograd, FPN, US Embassy.

Parker Kim et al (2020), "Economic Fallout from COVID-19 Continues to Hit LowerIncome Americans the Hardest", Pew Research Center, 24 September, online https://www. pewresearch.org/social-trends/2020/09/24/economic-fallout-from-covid-19-continues-tohit-lower-income-americans-the-hardest/.

Robinson, I. William (2014), Global Capitalism and Crisis of Humanity, New York: Cambridge University Press.

SIPRI (2021), "World military spending rises to almost \$2trillion in 2020", www.sipri.org, 26 April 2021.

Vankovska Biljana (2020), "Dealing with COVID-19 in the European periphery:between securitization and 'gaslighting' ", Journal of Global Faultlines, vol. 7, no. 1, 71-88.

Zakaria Fareed (2020), "The pandemic upended the present. But it's given us a chance to remake the future", Washington Post, 6 October, online https://www.washingtonpost.com/ opinions/2020/10/06/fareed-zakaria-lessons-post-pandemic-world/. 
Zizek Slavoj (2020), "Coronavirus is 'Kill Bill'-esque blow to capitalism and could lead to reinvention of communism", Russia Today, 27 February, online https://www.rt.com/oped/481831-coronavirus-kill-bill-capitalism-communism/.

Zuboff Shoshana (2019), The Age of Surveillance Capitalism, the Fight for a Human Future at the New Frontier of Power, New York: Public Affairs. 